\title{
Pengembangan media pembelajaran kimia menggunakan video untuk mengukur kemampuan berfikir kritis siswa
}

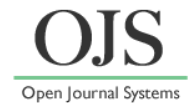

\author{
Rina Endriani $^{{ }^{*}}$, Agus Sundaryono ${ }^{1}$, Rina Elvia ${ }^{2}$ \\ ${ }^{1}$ Pascasarjana Pendidikan IPA FKIP Universitas Bengkulu, Bengkulu \\ ${ }^{2}$ Pendidikan Kimia FKIP Universitas Bengkulu, Bengkulu \\ *Email: rinanasri78@gmail.com
}

\begin{abstract}
ABSTRAK
Penelitian ini bertujuan untuk mengembangkan media pembelajaran dalam bentuk video pembelajaran kimia dan digunakan untuk mengukur kemampuan berpikir kritis siswa. Metode yang digunakan adalah penelitian dan pengembangan (Research and Development) pembelajaran kimia pada bahan minyak bumi dengan model Dick dan Carey, melalui tahapan: desain, validasi, revisi dan tes formatif untuk siswa kelas XI di SMAN 1 Bengkulu Tengah. Kemampuan berpikir kognitif siswa dapat diukur dan dilihat dari hasil tes formatif, data yang diperoleh dalam bentuk data kuantitatif dan dilakukan analisis deskriptif untuk menilai kemampuan berpikir kritis siswa. Berdasarkan hasil tes formatif, 13,3\% siswa kurang kritis, 60\% siswa kritis, 20\% siswa kritis dan 6,67\% sangat penting.
\end{abstract}

Kata kunci: Pengembangan; media; pembelajaran kimia; video; berfikir kritis.

\section{PENDAHULUAN}

Sumber pembelajaran kimia di sekolah pada umumnya bersumber dari buku-buku pegangan dan guru sebagai fasilitator. Kurangnya contoh-contoh konkrit yang bersinggungan langsung dengan kehidupan membuat proses belajar menjadi kurang menarik minat siswa. Realitas pendidikan dilapangan, banyak pendidik yang masih menggunakan sistem belajar satu arah (one way) yang kurang bervariasi, sehingga suasana belajar membosankan dan tidak dapat mengembangkan pola berfikir kritis siswa. Siswa dituntut memiliki keterampilan berfikir kritis, berfikir kreatif, berfikir pemecahan masalah dan berfikir metakognitif melalui pembelajaran yang kaya dan bermakna (Soviawati, 2011, Mulyana, 2008, Ismaimuza, 2013). Masalah dalam dunia pendidikan di abad 21 ini sangat beragam dan kompleks. Dalam konteks abad ini siswa dituntut harus memiliki performa yang tinggi serta penguasaan mendalam seluruh materi pembelajaran. Lebih jauh siswa diharuskan mampu memperoleh keterampilan berfikir kritis untuk menghadapi tantangan zaman yang lebih kompleks.

Sugiyono (2009) berpendapat bahwa, metode penelitian dan pengembangan (Research and Development) adalah metode penelitian yang digunakan untuk menghasilkan produk tertentu, dan menguji keefektifan produk tersebut. Untuk dapat menghasilkan produk tertentu digunakan penelitian yang bersifat analisis kebutuhan (digunakan metode survey atau kualitatif) dan untuk menguji keefektifan produk tersebut supaya dapat berfungsi di masyarakat luas, maka diperlukan penelitian untuk menguji keefektifan produk tersebut (digunakan metode eksperimen).

Dalam bidang pendidikan, produkproduk yang dihasilkan melalui penelitian Research and Development diharapkan dapat meningkatkan produktivitas pendidikan, yaitu lulusan yang jumlahnya banyak, berkualitas, dan relevan dengan kebutuhan. Produk-produk pendidikan yang dihasilkan dapat berupa kurikulum yang spesifik untuk keperluan pendidikan tertentu, metode mengajar, media pendidikan, buku ajar, modul, kompetensi tenaga kependidikan, sistem evaluasi, model uji kompetensi, penataan ruang kelas untuk model pembelajar tertentu, model unit produksi, model manajemen, sistem pembinaan pegawai, sistem penggajian dan lain-lain (Sugiyono, 2009).

Model prosedural Dick and Carey merupakan model penelitian yang berorientasi pada pemaparan tahapan penelitian secara deskriptif. Secara umum tahapan-tahapan dalam penelitian ini terdiri atas tiga bagain yakni: tahapan pra-pengembangan, pengembangan dan pasca-pengembangan. 
Sudjana dan Rivai (2011) menyatakan bahwa banyak sekali manfaat dalam penggunaan media pembelajaran dalam proses belajar siswa, diantaranya yaitu: pembelajaran akan lebih menarik perhatian siswa sehingga dapat menumbuhkan motivasi belajar, bahan pelajaran akan lebih jelas maknanya sehingga dapat lebih dipahami oleh siswa dan memungkinkan menguasai dan mencapai tujuan pembelajaran, metode mengajar akan lebih bervariasi, tidak semata-mata komunikasi verbal melalui penuturan kata-kata oleh guru, siswa dapat lebih banyak melakukan kegiatan belajar sebab tidak hanya mendengarkan uraian guru, tetapi juga aktivitas lain seperti mengamati, melakukan mendemonstrasikan, memamerkan dan lain-lain. Model pembelajaran yang digunakan oleh pendidik harus sesuai dengan kebutuhan pembelajaran yang efektif, maksudnya pemilihan model pembelajaran yang tepat akan membantu siswa menguasai materi pelajaran sesuai dengan target yang ditempuh dalam kurikulum (Yamin, 2013). Salah satu sumber belajar adalah penggunaan media pembelajaran yang berbentuk visual yaitu berbentuk video.

Kustandi dan Bambang (2013), mengungkapkan beberapa keuntungan apabila menggunakan media video dalam pembelajaran, yaitu:

- Video dapat melengkapi pengalamanpengalaman dasar dari siswa ketika siswa berdiskusi, membaca, dan praktik.

- Video dapat menunjukan objek secara normal yang tidak dapat dilihat, seperti kerja jantung ketika berdenyut.

- Mendorong dan meningkatkan motivasi siswa serta menanamkan sikap dan segi afektif lainnya.

- Video mengandung nilai-nilai positif yang dapat mengundang pemikiran dan pembahasan dalam kelompok siswa.

- Video dapat menyajikan peristiwa kepada kelompok besar atau kelompok kecil dan kelompok yang heterogen atau perorangan.

Menurut Ennis, dalam mengidentifikasi 12 indikator berpikir kritis, dapat dikelompokkan ke dalam lima besar aktivitas. Adapun pengelompokkan keterampilan berpikir kritis disajikan pada tabel indikator keterampilan berfikir kritis pada tabel 1 .
Tabel 1. Indikator Keterampilan Berfikir Kritis menurut Robert H. Ennis

\begin{tabular}{|c|c|}
\hline $\begin{array}{l}\text { Berfikir } \\
\text { Kritis }\end{array}$ & Sub Berfikir Kritis \\
\hline \multirow{3}{*}{$\begin{array}{l}\text { 1. Memberikan } \\
\text { penjelasan } \\
\text { sederhana }\end{array}$} & $\begin{array}{l}\text { 1. Memfokuskan } \\
\text { pertanyaan }\end{array}$ \\
\hline & $\begin{array}{l}\text { 2. Menganalisis } \\
\text { pertanyaan dan bertanya }\end{array}$ \\
\hline & $\begin{array}{l}\text { 3. Menjawab pertanyaan } \\
\text { tentang suatu penjelasan } \\
\text { dan tantangan }\end{array}$ \\
\hline \multirow[t]{2}{*}{$\begin{array}{l}\text { 2. Membangun } \\
\text { keterampilan } \\
\text { dasar }\end{array}$} & $\begin{array}{l}\text { 4. Mempertimbangkan } \\
\text { apakah sumber dapat } \\
\text { dipercaya atau tidak }\end{array}$ \\
\hline & $\begin{array}{l}\text { 5. Mengamati serta } \\
\text { mempertimbangkan } \\
\text { hasil deduksi }\end{array}$ \\
\hline \multirow[t]{3}{*}{$\begin{array}{l}\text { 3. Menyimpulk } \\
\text { an }\end{array}$} & $\begin{array}{l}\text { 6. Mendeduksi atau } \\
\text { mempertimbangkan } \\
\text { hasil induksi }\end{array}$ \\
\hline & $\begin{array}{l}\text { 7. Mendeduksi atau } \\
\text { mempertimbangkan } \\
\text { hasil induksi }\end{array}$ \\
\hline & $\begin{array}{l}\text { 8. Membuat } \\
\text { menentukan } \\
\text { pertimbangan }\end{array}$ \\
\hline \multirow[t]{2}{*}{$\begin{array}{l}\text { 4. Memberikan } \\
\text { penjelasan } \\
\text { lanjut }\end{array}$} & $\begin{array}{l}\text { 9. Mengidentifikasi } \\
\text { istilah-istilah dan } \\
\text { defenisi pertimbangan } \\
\text { serta dimensi }\end{array}$ \\
\hline & $\begin{array}{l}\text { 10. Mengidentifikasi } \\
\text { asumsi }\end{array}$ \\
\hline \multirow{2}{*}{$\begin{array}{l}\text { 5. Mengatur } \\
\text { strategi dan } \\
\text { teknik } \\
\end{array}$} & 11.Menentukan tindakan \\
\hline & $\begin{array}{c}\text { 12. Berinteraksi } \\
\text { orang lain }\end{array}$ \\
\hline
\end{tabular}

\section{METODE PENELITIAN}

\section{Subjek Penelitian dan Lokasi Penelitian}

Penelitian dilakukan pada semester ganjil tahun akademik 2017-2018. Subjek penelitian adalah siswa kelas XI SMAN 1 Bengkulu Tengah berjumlah 15 siswa.

Prosedur Pengembangan Perangkat Pembelajaran

Metode penembangan pembelajaran pada penelitian ini adalah Penelitian dan Pengembangan (Research and Development) dengan model Dick and Carey. Model Dick Carey adalah model pendekatan prosedural yang dikembangkan oleh Walter Dick, Lou Carey dan James O. Carey dalam The 
Systematic Design of Instruction Edisi ke-7 tahun 2009 (Dick, et al. 2009). Langkahlangkah yang akan dilakukan dalam penelitian ini adalah sebagai berikut:

Tahap 1 (Merancang / perencanaan serta pengembangan kegiatan pembelajaran.

Tahap ini meliputi:

- Menentukan tujuan pembelajaran. Peneliti terlebih dahulu menentukan tujuan pembelajaran yang diharapkan dapat dicapai siswa setelah melaksanakan pembelajaran.

- Melakukan analisis pembelajaran. Analisis pembelajaran bertujuan untuk menidentifikasi kompetensi atau keterampilan yang harus dipelajari siswa, meliputi KI, KD, materi, instrumen penilaian dan indikator penilaian.

- Pengembangan instrumen penilaian. Instrumen penilaian yang akan dikembangkan adalah penilaian kognitif terhadap kemapuan berfikir kritis. Penilaian dilakukan dengan pemberian skor untuk setiap jawaban yang diberikan oleh siswa.

- Pengembangan strategi pembelajaran. Pengembangan strategi pengajaran yang digunakan selama kegiatan pembelajaran yang akan dilakukan untuk mencapai tujuan akhir, yaitu dengan video pembelajaran.

- Pengembangan perangkat pembelajaran. Adapun bahan ajar yang digunakan dalam penelitian pendidikan ini adalah video pembelajaran, silabus, RPP, dan instrumen penilaian kognitif (untuk mengukur kemampuan berfikir kritis siswa).

Tahap 2 (validasi)

Pada tahap ini dilakukan kegiatan validasi terhadap perangkat pembelajaran yang sudah dikembangkan. Kegiatan validasi oleh ahli (expert judgement) dilakukan oleh guru senior dan dosen. Adapun perangkat pembelajaran yang akan divalidasi adalah video pembelajaran, silabus, RPP, soal berfikir kritis.

Tahap 3 (Revisi)

Pada tahap ini dilakukan revisi atau perbaikan terhadap perangkat pembelajaran yang sudah divalidasi oleh ahli (expert judgement).

\section{Tahap 4 (Uji coba / uji formatif)}

Perangkat pembelajaran yang sudah direvisi pada tahap tiga diatas selanjurnya dilakukan uji (uji formatif). Uji pembelajaran dilakukan dikelas XI SMAN 1 Bengkulu Tengah dengan media video pembelajaran.

Jenis data dan instrumen penilaian

\section{Jenis Data}

Jenis data dari uji coba berupa data kuantitatif. Data kuantitatif diperoleh dari hasil tes uji formatif untuk menilai keterampilan berfikir kritis siswa dan kelayakan hasil pengembangan perangkat pembelajaran.

\section{Instrumen Penilaian dan Indikator}

Pada proses penilaian yang dilakukan pada penelitian ini adalah: Penilaian Kompetensi Berfikir Kritis yaitu berupa penilaian kemampuan berfikir kritis siswa. Instrumen yang digunakan berupa soal berfikir kritis (Ennis, 1991).

Analisis Data hasil Penelitian Pengembangan Perangkat Pembelajaran

Analisis soal digunakan untuk menganalisis kemampuan berfikir kritis siswa. Pada soal kemampuan berfikir kritis terdapat 5 butir indikator yang meliputi kemampuan memfokuskan masalah, menganalisis argumen, mempertimbangkan hasil deduksi, dan mengidentifikasi asumsi. Pengukuran skor kemampuan berfikir kritis siswa menggunakan persamaan berikut:

Nilai Kemampuan Berfikir

Kritis $=\frac{\text { jumlah skor } \text { yang diperoleh }}{\text { jumlah skor maksimal }} \times 100$

Dimana , $\quad 80<\mathrm{x} \leq 100$ : sangat krits

$$
\begin{aligned}
& 60<\mathrm{x} \leq 80 \text { : kritis } \\
& 40<\mathrm{x} \leq 60 \text { : cukup kritis } \\
& 20<\mathrm{x} \leq 40 \text { : } \text { kurang kritis } \\
& 0,0<\mathrm{x} \leq 20 \text { : tidak kritis }
\end{aligned}
$$

(Karyadi, 2016)

Data yang diperoleh berupa data kuantitatif (diperoleh dari hasil tes uji coba skala kecil) untuk menilai kemampuan berfikir kritis siswa dan kelayakan hasil pengembangan perangkat pembelajaran), dilakukan analisis secara deskriptif. 


\section{HASIL DAN PEMBAHASAN}

Pengembangan pembelajaran kimia pada pokok bahasan minyak bumi, dalam bentuk video pembelajaran yang digunakan sebagai sumber belajar. Video pembelajaran digunakan untuk mengukur kemampuan berfikir kritis pada siswa. Penelitian pengembangan pembelajaran ini dilakukan dengan model Dick and Carey yaitu uji coba skala kecil dengan 15 orang siswa kelas XI di SMAN 1 Bengkulu Tengah.

\section{Merancang Kegiatan Pembelajaran}

Tahap awal pada penelitian ini adalah merancang serta mengembangkan kegiatan pembelajaran, yaitu menentukan tujuan pembelajaran, melakukan analisis pembelajaran (meliputi KI, KD, materi, instrumen penilaian dan indikator penilaian), mengembangkan instrumen penilaian, mengembangkan strategi penilaian dan mengembangkan perangkat pembelajaran.

\section{Uji Validasi Video Pembelajaran}

Video pembelajaran dibuat dengan isi materi tentang minyak bumi dan energi alternatif. Dari hasil uji validasi video pembelajaran bahwa nilai ICC yang dihasilkan adalah 0,61 . Nilai ICC $\geq 0,6$ termasuk kriteria baik, yang artinya penilaian dari validator dapat diterima. Terdapat beberapa saran yang perlu diperbaiki pada isi / konten video yaitu : merevisi narasi, membuat korelasi antara narasi dengan inti video dan memperbaiki kualitas suara pada video. Saran-saran dari validator tersebut akan dijadikan bahan untuk merevisi produk yang nantinya akan digunakan dalam pembelajaran bisa menjadi lebih sempurna dan memenuhi standar kriteria media pembelajaran.

\section{Uji Validasi Soal}

Validasi juga dilakukan terhadap soal formatif yang akan digunakan sebagai alat ukur kemampuan berfikir kritis siswa. Para panelis diminta untuk memberi penilaian soal formatif berdasarkan instrumen validasi soal yang disediakan yaitu dengan 2 penilaian sesuai atau tidak sesuai dengan keterampilan berpikir siswa yang diukur sesuai dengan indikator.

\section{Uji Coba Soal Oleh Siswa}

Sebelum digunakan sebagai alat pengumpul data, maka instrumen tersebut harus diuji coba terlebih dahulu agar memenuhi syarat sebagai alat ukur. Uji coba evaluasi dilakukan pada siswa kelas XI MIPA yang terdiri dari 15 orang siswa. Instrumen yang diujicobakan dalam penelitian ini berupa lembar tes keterampilan berpikir kritis. Butir soal yang di uji cobakan sebanyak 10 butir soal. Selanjutnya dilakukan analisis instrumen tes dilakukan terhadap validitas soal, reabilitas, dan tingkat kesukaran dan daya beda. Hasil analisis validasi uji coba soal dapat dilihat pada tabel 2.

Tabel 2. Hasil analisis validasi uji coba

\begin{tabular}{|c|c|c|c|c|c|c|}
\hline \multirow[b]{2}{*}{$\begin{array}{l}\mathbf{N} \\
\mathbf{0}\end{array}$} & \multicolumn{6}{|c|}{ Materi 1} \\
\hline & $\begin{array}{c}\mathbf{f} \\
\text { Kesu } \\
\text { kara } \\
\mathbf{n}\end{array}$ & $\begin{array}{c}\text { Kriteri } \\
\mathbf{a}\end{array}$ & $\begin{array}{c}\text { Daya } \\
\text { pembe } \\
\text { da }\end{array}$ & $\begin{array}{c}\text { Kriteri } \\
\mathbf{a}\end{array}$ & $\begin{array}{c}\text { Vali } \\
\text { ditas }\end{array}$ & $\begin{array}{c}\text { Kriteri } \\
\mathbf{a}\end{array}$ \\
\hline 1 & 0,83 & Mudah & 0,58 & $\begin{array}{c}\text { Sangat } \\
\text { Baik }\end{array}$ & $\begin{array}{c}0,66 \\
3\end{array}$ & Valid \\
\hline 2 & 0,67 & Sedang & 0,50 & $\begin{array}{c}\text { Sangat } \\
\text { Baik }\end{array}$ & $\begin{array}{c}0,67 \\
7\end{array}$ & Valid \\
\hline 3 & 0,65 & Sedang & 0,35 & Baik & $\begin{array}{c}0,49 \\
7 \\
\end{array}$ & $\begin{array}{l}\text { Tidak } \\
\text { Valid } \\
\end{array}$ \\
\hline 4 & 0,53 & Sedang & 0,38 & Baik & $\begin{array}{c}0,74 \\
7\end{array}$ & Valid \\
\hline 5 & 0.79 & Mudah & 0,58 & $\begin{array}{c}\text { Sangat } \\
\text { Baik }\end{array}$ & $\begin{array}{c}0,48 \\
8 \\
\end{array}$ & $\begin{array}{l}\text { Tidak } \\
\text { Valid }\end{array}$ \\
\hline 6 & 0,75 & Sedang & 0,54 & $\begin{array}{c}\text { Sangat } \\
\text { Baik }\end{array}$ & $\begin{array}{c}0,59 \\
7 \\
\end{array}$ & Valid \\
\hline 7 & 0,35 & Sedang & 0,31 & Baik & $\begin{array}{c}0,56 \\
3\end{array}$ & Valid \\
\hline 8 & 0,48 & Sedang & 0,23 & $\underset{\text { um }}{\text { Minim }}$ & $\begin{array}{c}0,07 \\
0 \\
\end{array}$ & $\begin{array}{l}\text { Tidak } \\
\text { Valid }\end{array}$ \\
\hline 9 & 0,58 & Sedang & 0,42 & Baik & $\begin{array}{c}0,68 \\
2\end{array}$ & Valid \\
\hline $\begin{array}{l}1 \\
0 \\
\end{array}$ & 0,67 & Sedang & 0,50 & $\begin{array}{c}\text { Sangat } \\
\text { Baik }\end{array}$ & $\begin{array}{c}0,81 \\
5 \\
\end{array}$ & Valid \\
\hline
\end{tabular}

Soal yang telah valid selanjutnya dapat digunakan sebagai instrumen untuk mengukur kemampuan berfikir kritis siswa, yaitu soal no 2, 4, 6, 7 dan 9. Sebelum dilakukan uji formatif, terlebih dahulu terhadap siswa dilakukan pembelajaran menggunakan video. Setelah pembelajaran menggunakan video, dilakukan pengukuran keterampilan berfikir kritis siswa dengan menggunakan tes formatif soal berfikir kritis.

\section{Hasil Kemampuan Berpikir Kritis Siswa}

Kemampuan berpikir kritis secara kognitif siswa dapat diukur dan dilihat dari hasil tes formatif yang diberikan. Tingkat kemampuan ini ditinjau melalui indikator keterampilan berpikir kritis yang digunakan. 
Kemampuan berpikir kritis siswa pada penelitian ini menggunakan 5 indikator keterampilan berpikir kritis yaitu yaitu:

1) Memberikan penjelasan sederhana,

2) Membangun keterampilan dasar

3) Menyimpulkan,

4) Memberikan penjelasan lanjut, dan

5) Mengatur strategi dan asumsi.

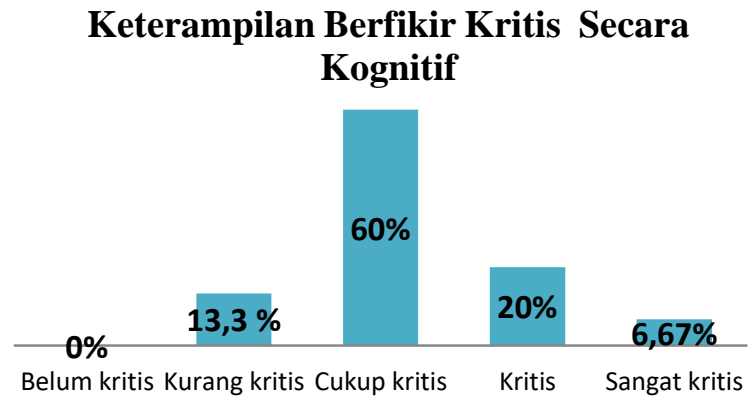

Gambar 1. Grafik keterampilan berfikir kritis secara kognitif

Berdasarkan hasil analisis terhadap nilai kemampuan berfikir kritis, nilai indikator berfikir kritis tertinggi dengan terdapat pada indikator memberikan penjelasan sederhana, dengan nilai rata-rata $86,7 \%$, pada soal dengan indikator ini siswa telah berfikir kritis. Sedangkan nilai indikator berfikir kritis terendah pada indikator memberikan penjelasan lanjut dengan nilai rata-rata $35,6 \%$, pada soal dengan indikator ini dapat disimpulkan bahwa siswa belum berfikir kritis. Pada indikator berfikir kritis membangun keterampilan dasar (nilai rata-rata 48\%), menyimpulkan (nilai rata-rata $44 \%$ ) serta mengatur startegi dan teknik (nilai rata-rata 44\%) berdasarkan nilai rata-rata tersebut dapat disimpulkan bahwa siswa cukup berfikir kritis. Nilai rata-rata keterampilan berfikir kritis secara kognitif pada siswa dapat dilihat pada gambar grafik keterampilan berfikir kritis.

\section{KESIMPULAN}

Hasil pengukuran kemampuan berfikir kritis siswa pada pembelajaran kimia menggunakan video menunjukkan bahwa 13,3 $\%$ siswa kurang kritis, $60 \%$ siswa cukup kritis, $20 \%$ siswa kritis dan $6,67 \%$ siswa sangat kritis.

\section{DAFTAR PUSTAKA}

Dick, Walter, Lou Carey and James O. Carey. (2009). The Sustematic Design of Instruction 7th edition. Florida. Harper Collins Pub.

Ennis, Robert. (1991). Critical Thinking: A streamlined Conception. University of Illinois: Artikel Theaching Philosophy.

Ismaimuza, D. (2013). Kemampuan Berpikir Kritis dan Kreatif Matematis Siswa SMP melalui Pembelajaran Berbasis Masalah dengan Strategi Konflik Kognitif. Sains Humanika, 63(2).

Karyadi, Bhakti (2016). Pengembangan Model Pembelajaran di Luar Kelas (Outdoor) Berbasis Lingkungan Alam Bagi Siswa SD-SMA Bengkulu: Universitas Bengkulu.

Kustandi, Cecep dan Bambang Sutjipto. (2013). Media Pembelajaran Manual danDigital disi Kedua. Bogor: Ghalia Indonesia.

Mulyana, T. (2008). Pembelajaran analitik sintetik untuk meningkatkan kemampuan berpikir kritis dan kreatif matematika siswa SMA. Disertasi. Tersedia di http://repository. upi. edu [diakses $20 \mathrm{Mei}$ 2012].

Soviawati, E. (2011). Pendekatan matematika realistik (pmr) untuk meningkatkan kemampuan berfikir siswa di tingkat sekolah dasar. Jurnal Edisi Khusus, 2(2), 79-85.

Sudjana, Nana dan A. Ahmad Rivai. (2011). Media Teaching. Bandung. New Light.

Sugiyono. (2009). Metode Penelitian Pendidikan Pendekatan Kuantitatif, Kualitatif, $R \& D$. Bandung: Alfabeta.

Yamin, Martins. (2003) Strategi dan Metode Dalam Model Pembelajaran. Jakarta. GP. Press G. 